\title{
Self-Concept and Academic Achievement of Students at the Higher Secondary Level
}

\author{
Archana Kumari \\ Research Scholar \\ N.K.T. National College of Education for Women, Chennai-600 005, Tamilnadu, India \\ Email: archanapandey14@gmail.com \\ Dr. S. Chamundeswari \\ Associate Professor, N.K.T. National College of Education for Women, Chennai-600 005, \\ Tamilnadu, India \\ Email: rajchamu2006@yahoo.co.in
}

Accepted: May 03, 2013 Published: June 25, 2013

Doi:10.5296/jsr.v4i2.3909 URL: http://dx.doi.org/10.5296/jsr.v4i2.3909

\begin{abstract}
Self-concept is the cognitive aspect of self and generally refers to the totality of a complex, organized and dynamic system of learned beliefs, attitudes and opinions that each person holds to be true about his or her personal existence. Self-concept and achievement are dynamically interactive and reciprocal. It is found that certain psychological factors like self-concept plays a major role in determining the academic achievement of students. Hence the need for this study. A sample of 321 students in different categories of schools following different systems of education at the higher secondary level was chosen. The findings of the study conducted revealed that students belonging to central board schools were better in their self-concept and academic achievement when compared to students from other boards. There is also a significant and positive relationship between self-concept and academic achievement of students at the higher secondary level.
\end{abstract}

Keywords: Self-concept, Academic Achievement, Psychological factors

\section{INTRODUCTION}

By self, we generally mean the conscious reflection of one's own being or identity, as an object separate from others or from the environment. There are a variety of ways to think about the self. Two of the most widely used terms are self-concept and self-esteem. Self-concept is the cognitive or thinking aspect of self (related to one's self-image) and generally refers to the 
totality of a complex, organized, and dynamic system of learned beliefs, attitudes and opinions that each person holds to be true about his or her personal existence (Purkey, 1988). According to Franken (1994), there is a great deal of research which shows that self-concept is, perhaps, the basis for all motivated behaviour. It is the self-concept that gives rise to possible selves, and it is possible selves that create the motivation for behaviour. This supports the idea that one's paradigm or world view and one's relationship to that view provide the boundaries and circumstances within which we develop our vision about possibilities. This is one of the major issues facing children and youth today (Huitt, 2004).

Self-concept and achievement are dynamically interactive and reciprocal, each is mutually reinforcing to the extent that a positive (or negative) change in one facilitates a commensurate change in the other and academic self-concept is more highly correlated with academic achievement than in general self-concept. Students with high self-concept tend to approach school related tasks with confidence and success of those tasks reinforces this confidence. The opposite pattern is likely to occur for children with low academic self-concepts.

\subsection{Self-concept}

The concept of self has three major components-the perceptual, the conceptual and the attitudinal. The perceptual component is the image the person has of the appearance of his body and the impression he makes on others. The perceptual component is often called the 'physical concept'. The conceptual component is the person's conception of his distinctive characteristics, abilities, background and origin and future. It is often called the 'psychological self-concept' and is composed of such life adjustment qualities, such as, honesty, self-confidence, independence, courage and their opposites. Included in the attitudinal component are the feelings a person has about himself, his attitude, his present status and future prospectus, his feelings about his worthiness and his attitudes of self-esteem, self-reproach, pride and shame.

James (1980) was the first to suggest that a person has many selves. The real self for example, is what a person really believes he is, ideal self the person he aspires to be and social self is what he believes, what others think of him and how they perceive him. The four categories of self-concept are the basic, the transitory, the social and the ideal.

\subsection{Academic Achievement}

Academic achievement is the amount of knowledge derived from learning. The child gains knowledge by instructions he/ she receives at school and are organized around a set of core activities in which a teacher assigns tasks to pupils and evaluates and compares the quality of their work. The school provides a wide variety of achievement experiences than does the family. According to Levy (1942), academic performance is based on the number of factors, such as children's attitudes, interest, personality characteristics and social class in addition to learning.

The concept of achievement has several references. It usually denotes activity and mastery, making an impact on the environment and competing against some standard of excellence. 


\section{Mll Macrothink}

The under achieving child is one whose actual attainment, as indicated by his scholastic attainment in school, does not measure up to his potential achievement as indicated by his abilities. Levy (1942) also defined over achievers as pupils whose school attainment is in excess of expectations formed on the basis of their activities. The concept of over and under achievement suggests that there are variables in addition to ability which have positive effects on performance and that there is no perfect positive correlation between intelligence and attainment.

\subsection{Need for the Present Study}

Labeling of children based on school performance as under achievers or over achievers tends to suggest that intelligence is not the sole basis of predicting achievement and agrees that there are other variables influencing achievement. This leads us to the question of discovering other variables predicting achievement. It is found that certain psychological factors, like self-concept plays a major role in determining the academic achievement of students (Shah, 1990). Hence it becomes very essential for the researches to ascertain the influence of self-concept on the academic achievement of students. Hence, the investigators felt the need to select this vital area for the present investigation. Thus, the objectives of the present study are as follows:

$>$ To investigate if there is any significant difference in self-concept and academic achievement among students studying in state, matriculation and central board schools at the higher secondary level and

$>$ To investigate if there is any significant relationship between the select variables among students in state, matriculation and central board schools at the higher secondary level.

\section{REVIEW OF RELATED LITERATURE}

A positive self-concept is valued as a desirable outcome in many disciplines of psychology as well as an important mediator to other outcomes. According to the research and a comprehensive meta-analysis conducted by Marsh and Martin (2011), self-concept has a direct and indirect effect on subsequent achievement. Not only is self-concept an important outcome variable in itself, it also plays a central role in affecting other desirable educational outcomes. The studies reviewed pertaining to self-concept and academic achievement are compiled and presented hereunder.

Coover and Murphy (2000) conducted a study that examined the relationship between self-identity and academic persistence and achievement in a counter stereotypical domain. The study revealed that the higher the self-concept and self-schema, the more positive the self-descriptions, the better the academic achievement at 18. The study also showed that self-identity improves through social interaction and communication with others, which would enhance achievement.

Abisamra (2000) conducted a study to see whether there is a relationship between emotional intelligence and academic success. The population of the study was five hundred $11^{\text {th }}$ graders-boys and girls-- from public and private schools in Montgomery, Alabama. The 
sampling was stratified, making sure that schools, genders, races, socio-economic status, and abilities will be appropriately represented. The sample was given the Bar-On Emotional Quotient Inventory (EQ-i) which is the first scientifically developed and validated measure of emotional intelligence. The Bar-On EQ-i consists of 133 items that took approximately 30 minutes to complete. Grades were compared with the Emotional Intelligence level of each student and a relationship between emotional intelligence and academic achievement was found to be significantly positive.

Pujar and Gaonkar (2000) analyzed the influence of age and type of family on self-concept of adolescents belonging to high and low achieving English medium high school students in Dharwad city. The results of the study indicated that mode of expression of self-concept among both high and low achieving adolescents improved with age and the self-concept of students from nuclear families was higher than that of those from the joint families.

Kevin (2000) examined the academic self-concept construct in a sample of 206 African American students attending Historically Black Colleges and Universities (HBCUs) and Predominantly White Colleges and Universities (PWCUs). Findings indicated that the best predictor of academic self-concept for students attending PWCUs was grade point average, whereas the best predictor of academic self-concept for students attending HBCUs was quality of student-faculty interactions. Additional analyses indicated that grade point average is significantly more important for the academic self-concept of African American students attending PWCUs than African American students attending HBCUs.

The study conducted by Patwardhan (2002) explored self-concept of students in two stages- a) gender and grade differences, and b) its relation with future identity. Self-concept is one's overall idea of a sense of self, with multi dimensions of self in reference to others. Future identity refers to youth's awareness of life's work in future. In the first stage, 381 students (191 females and 190 males, from seventh grade through under-graduate level) attempted an inventory measuring multi dimensions of self-concept. They showed a high level of self-concept, with no significant gender differences. The difference in two extreme grades was significant. In the second stage, 30 undergraduate students attempted two inventories measuring self-concept and future identity. The correlation between these two components was weak.

Marsh and Koller (2004) used the longitudinal data (five waves) from large cohorts of 7th grade students in East Germany $(n=2,119)$ and West Germany $(n=1,928)$ which were collected from the start of the reunification of the school systems following the fall of the Berlin Wall. They integrated the two major theoretical models of relations between academic self-concept and achievement. They found that in support of the reciprocal effects model, prior self-concept and prior achievement had significant effects on subsequent self-concept and subsequent achievement and in support of the internal/ external frame of reference model. Mathematics achievement had a positive effect on Mathematics self-concept but a negative effect on German self-concept, whereas German achievement had a positive effect on German self-concept but a negative effect on Mathematics self-concept. Consistent with the unification of these models, prior self-concept in each school subject had positive effects on achievement in the same subject, but negative effects of achievement in the other school subject. Multi-group Structural Equation Models demonstrated that all predictions were 
supported for both East and West German students.

The major aim of the study conducted by Rana and Iqbal (2005) was to explore cause-effect relationship between the independent variables of students' self-concept and gender and the dependent variable of academic achievement in Science. Data were collected from 2142 students of grade 11 and 12 selected from 88 (44 male and 44 female) colleges throughout the Punjab. The results of the study showed that students' self-concept and gender has significant effect on their achievement in Science.

Manger and Eikeland (2006) in their study of the effect of Mathematics self-concept on girls' and boys' mathematical achievement found that Norwegian elementary schoolboys showed significantly higher Mathematics self-concept than girls. Boys also had a significantly higher mathematical achievement score than girls. However, controlling for Mathematics self-concept produced several interesting results. First, there was no significant effect of gender on overall mathematical achievement. Second, although the gender difference in achievement favouring boys increased with increasing task difficulty, no significant effects of gender were found in sub-samples of difficult tasks. Finally, a significant effect of gender favouring girls appeared in sub-samples of easy tasks and in routinizing well-defined procedural tasks. These results indicate that Mathematics self-concept is an important variable accounting for differences in elementary schoolgirls' and boys' Mathematical achievement.

Ishak and others (2010) examined the students' self-concept among 16- and 17- year- old adolescents in Malaysian secondary schools. A total of 1168 students participated in the survey. This study utilized the CoPs (UM) instrument to measure self-concept. Principal Component Analysis (PCA) revealed three factors: academic self-concept, physical self-concept and social self-concept. This study confirmed that students perceived certain internal context factors, and revealed that external context factor also have an impact on their self-concept which in turn influenced positively their academic performance.

Punithavathi (2011) conducted a research to investigate self-concept and academic achievement of students at the secondary level. The results of the analysis revealed a significant correlation between self-concept and academic achievement. Further a significant difference in self-concept and academic achievement was observed among students in different categories of school, namely, state, matriculation and central board schools. Corroborative studies were conducted by Kezhia (2012) and Subbulakshmi (2012).

The inclusive results in the previous researches and dearth of studies in the Indian context have initiated further investigation of self-concept and academic achievement of students.

\section{METHOD OF INVESTIGATION}

\subsection{Population and Sample Selection}

The target population for the present study was students in different categories of schools following different systems of education at the higher secondary level. From the target population, a sample of 321 students (106 state, 110 matriculation and 105 central board schools) was chosen. 


\subsection{Instrument}

The research tool used for the present study to analyze the self-concept of students in different systems of education at the higher secondary level is Self-concept Inventory (Sharma, 1967) and for academic achievement the achievement in all subjects was taken.

\section{ANALYSES AND INTERPRETATION}

Table-1 Analysis of Variance of Self-concept and Academic Achievement among Students in different Categories of Schools at the Higher Secondary Level

\begin{tabular}{|l|l|l|l|l|l|}
\hline \multirow{2}{*}{ Variable } & $\begin{array}{l}\text { Source of } \\
\text { Variation }\end{array}$ & $\boldsymbol{d} f$ & $\begin{array}{l}\text { Sum of } \\
\text { Squares }\end{array}$ & $\begin{array}{l}\text { Mean of } \\
\text { Sum of } \\
\text { Squares }\end{array}$ & \multirow{2}{*}{-ratio } \\
\hline \multirow{3}{*}{ Self-concept } & Between groups & 2 & 1630685.50 & 815342.75 & \multirow{2}{*}{$869.43 * *$} \\
\cline { 2 - 5 } & Within groups & 318 & 298214.73 & 937.78 & \\
\cline { 2 - 5 } & Total & 320 & 1928900.23 & - & \multirow{2}{*}{$4.94 * *$} \\
\hline \multirow{2}{*}{$\begin{array}{l}\text { Academic } \\
\text { Achievement }\end{array}$} & Between groups & 2 & 2048.55 & 1024.28 & \\
\cline { 2 - 6 } & Within groups & 318 & 65910.63 & 207.27 & \\
\cline { 2 - 5 } & Total & 320 & 67959.18 & - & \\
\hline
\end{tabular}

**Significant at 0.01 level

In Table-1, for the analysis of variance different categories of schools are treated as different groups. The $F$-ratios are 869.43 and 4.94 for self-concept and academic achievement respectively, which are significant at 0.01 level. Thus, there is a significant difference in self-concept and academic achievement among students in different categories of schools at the higher secondary level.

Inorder to establish the actual degree of difference between the students belonging to different categories of schools, namely, state, matriculation and central board schools, critical ratios were worked out and the actual difference between the mean scores were established. The tables presented below thus indicate the mean difference between the students in the different categories of schools at the higher secondary level.

Table-2. Statistical Analysis of Means of Self-concept and Academic Achievement among Students in State, Matriculation and Central Board Schools at the Higher Secondary Level

\begin{tabular}{|c|c|c|c|c|c|c|c|}
\hline Variable & $\begin{array}{l}\text { Category of } \\
\text { Schools }\end{array}$ & $\begin{array}{l}\text { Sample } \\
\text { Size }\end{array}$ & Mean & SD & SEM & SED & CR \\
\hline \multirow{3}{*}{ Self-concept } & State Board & 106 & 108.19 & 18.19 & 1.77 & \multirow[b]{2}{*}{3.99} & \multirow[b]{2}{*}{$20.61 * *$} \\
\hline & $\begin{array}{l}\text { Matriculation } \\
\text { Board }\end{array}$ & 110 & 190.36 & 36.96 & 3.52 & & \\
\hline & State Board & 106 & 108.19 & 18.19 & 1.77 & 3.68 & $47.75^{* *}$ \\
\hline
\end{tabular}




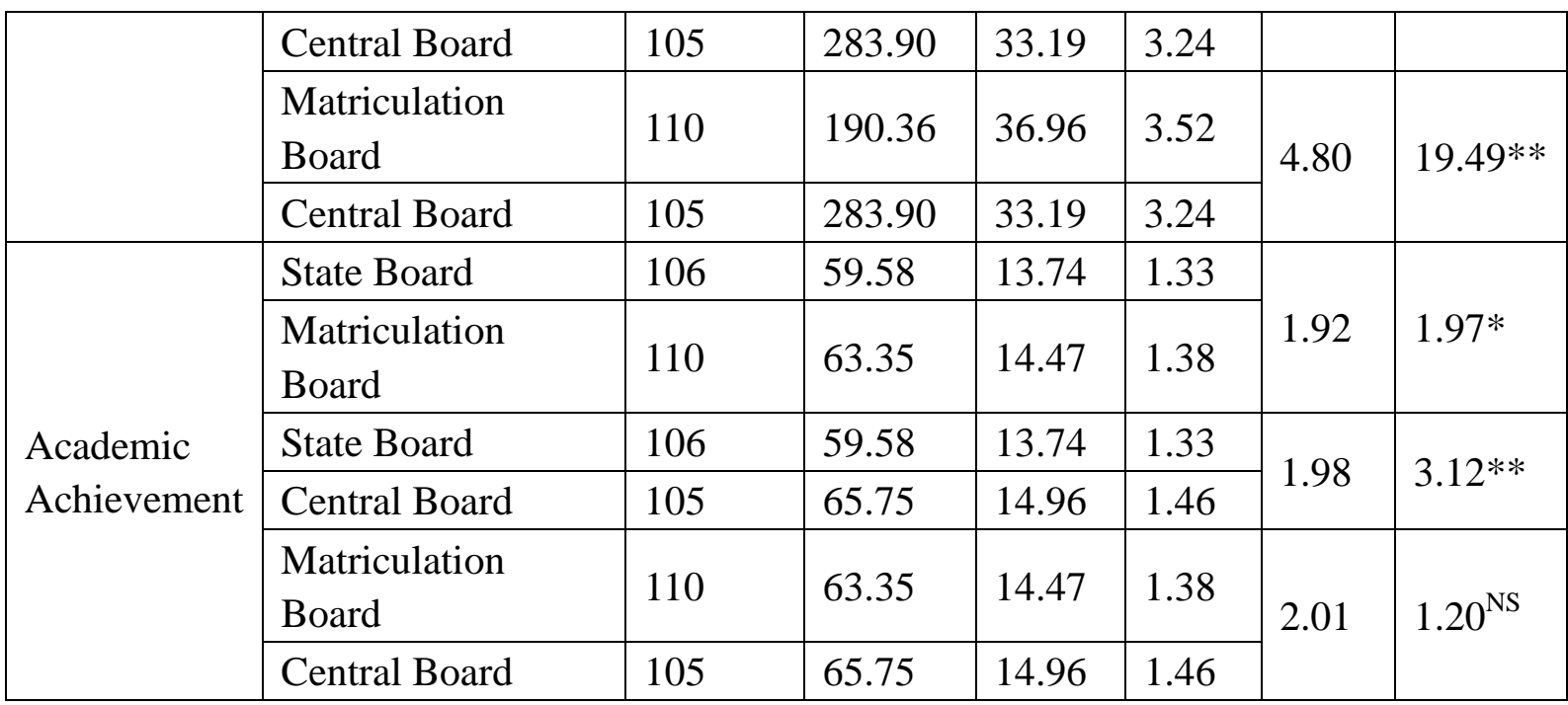

**Significant at 0.01 level

In Table-2, it is evident that the matriculation board school students are better in their self-concept when compared to the state board school students; the central board students are better in their self-concept when compared to the state board school students; the central board school students are better in their self-concept when compared to the matriculation board students at the higher secondary level.

In the above table (Table-2) it is also seen that the matriculation and central board school students are better in their academic achievement when compared to the state board students. But no such significant difference was observed between the matriculation and central board school students pertaing to their academic achievement at the higher secondary level.

Table-3. Analysis of Correlation between the Select Variables among Students at the Higher Secondary Level

\begin{tabular}{|l|l|l|}
\hline Variable & Self-concept & Academic Achievement \\
\hline Self-concept & 1 & $0.23^{* *}$ \\
\hline Academic Achievement & & 1 \\
\hline
\end{tabular}

**Significant at 0.01 level

From the above table (Table-3), it is evident that the select variables of the present study, namely, self-concept and academic achievement are all positively correlated with each other and significant at 0.01 level.

\section{SUMMARY}

Research performed over the years has suggested that there is a relationship between self-concept and academic achievement in higher secondary and secondary students. Society plays a dominant role in shaping self-concept of a person. Self is in fact a complex whole, which consists of several parts and sub-parts which have functional inter-relationship. Self is not an inborn quality; it develops gradually as a result of social interaction. It is the totality of attitudes, judgment and values of an individual relating to his behaviours, abilities and 
qualities. Marsh and Craven (1997) claimed that academic self-concept and achievement are mutually reinforcing constructs, each leading to gains in the other. Enhancing self-concept is a vital goal in and of itself and that self-concept is an important mediating variable that causally impacts on a variety of desirable outcomes including academic achievement (Marsh and Craven, 1997). From the present study, it is evident that there is a significant and positive relationship between the select variables, namely, self-concept and academic achievement of students in different categories of schools following different systems of education at the higher secondary level.

\section{REFERENCES}

AbiSamra, N. (2000). The relationship between Emotional Intelligent and Academic Achievement in Eleventh Graders. Research in Education, FED.661.

Agarwal, R. (1993). Relationship between some Psychological Variables and General Self-concept in Ninth Grade Students. Fifth Survey of Educational Research, 2,938.

Awasthi, B. (1992). A Study of Prolonged Deprivation, Self-concept and Scholastic Achievement. Fifth Survey of Educational Research, 2,1861.

Coover and Murphy (2000). Coover, G.E., and Murphy, S.T. (2000). The Communicated Self. Human Communication Research, 26(1),125-148.

Fisher, J.L. (1994). The Multidimensionality of Self-concept and its relationship to Academic Achievement. Dissertation Abstracts International, 56(2),493.

Franken, R. (1994). Human Motivation (3rd ed.). Pacific Grove, CA: Brooks/Cole Publishing Co.

Huitt, W. (2004). Becoming a Brilliant Star: An Introduction. Presentation at the Forum for Integrated Education and Educational Reform Sponsored by the Council for Global Integrative Education, Santa Cruz, CA.

Ishak, Z., Jamaluddin, S. and Chew, F.P. (2010). Factors Influencing Students' Self-Concept among Malaysian Students. World Academy of Science, Engineering and Technology, 66,800-803

James, W. (1980). Principles of Psychology, New York: Henry Holt.

Kevin, C. (2000). An Investigation of Academic Self-concept and its relationship to Academic Achievement in African American College Students Journal of Black Psychology, 26(2), pp.148-164.

Kezhia, T. (2012). Self-concept, Study Habits, School Environment, Socio-economic Status and Academic Achievement of Students at the Secondary Level, M.Phil. Thesis, Tamilnadu Teachers Education University, Chennai.

Levy, D.M. (1942) Maternal and Protection, New York, Columbia University Press.

Manger and Eikeland (2006 Manger, T. and Eikeland, O. (1998). The Effect of Mathematics Self-Concept on Girls' and Boys' Mathematical Achievement. School Psychology International, 19(1), pp. 5-18.

Maqsud, M. and Rouhani, S. (1990). Relationships between Socio-economic status Locus of Control self-concept, and Academic Achievement, School of Education, University of Bophuthatswana, Mmbatho 8681, Bophuthatswana, Southern Africa. 


\section{Macrothink}

Journal of Sociological Research

ISSN 1948-5468

2013, Vol. 4, No.2

Marsh H.W. and Martin, A.J. (2011). Academic Self-concept and Academic Achievement: Relations and Causal Ordering. British Journal of Educational Psychology, 81, pp. 59-77.

Marsh, H.W. (1992). Content Specificity of relations between Academic Achievement and Academic Self-concept. Journal of Education Psychology, 84(1), pp. 35-42.

Marsh, H.W. and Craven, R. (1997). Academic Self-concept: Beyond the Dustbowl, In G. Phye (Ed.),

Marsh, H.W. and Koller, O. (2004). Unification of Theoretical Models of Academic Self-concept/Achievement relations: Reunification of East and West German School Systems after the Fall of the Berlin Wall. Contemporary Educational Psychology, 29(3), pp. 264-282. Moultan, K.C. (1990). An Analysis of the Impact of a Social Skills Intervention on the Self-concept and Academic Achievement and Behavioural Pattern of $7^{\text {th }}$ Grade at Risk Students. Dissertation Abstracts International, 51(4), pp. 1168.

Patwardhan, V. (2002). Eritrean Exploring: Links with Gender, Grade, and Future Identity. IFE Psychological, 10(2), pp. 1-19

Pujar, L. and Gaonkar V. (2000). A Study to Know the Influence of Age and Type of Family on Self-concept of Adolescent Belonging to High and Low Achievers Group. Indian Psychological Review, 54(1-2), pp. 24-26.

Punithavathi, P. (2011). Creativity, Self-concept and Academic Achievement among Students at the Secondary Level, M.Ed. Thesis, Tamilnadu Teachers Education University, Chennai.

Purkey, W. (1988). An Overview of Self-concept Theory for Counselors. ERIC Clearinghouse on Counseling and Personnel Services, Ann Arbor, Mich. (An ERIC/CAPS Digest: ED304630)

Rana, R.A. and Iqbal, Z.F. (2005). Effect of Students' Self-Concept and Gender on Academic Achievement in Science. Bulletin of Education and Research, 27(2), pp. 19-36.

Shah J.H. (1990). A Study of Relationship among Intelligence and Academic Achievement of Pupils of Semi-urban and Rural Area. Survey of Educational Research, 2, pp. 1916.

Sharma, S. (1967). The Self Concept Inventory (SCI) Handbook of Psychological and Social Instruments. Indian Institute of Management, Ahemadabad.

Shasi Bhala, G. (1988). A Study on the Academic Motivation with Intelligence and Self-concept. Journal of Education of Psychology, 56(4).

Sicherer, M.J. (1995). A Relationship between Global Self-concept, Academic Self-concept and College Academic Achievement for Multicultural College Women. Dissertation Abstracts International.

Subbulakshmi, V. (2012). Mental Health, Self-concept and Academic Achievement among Students at the Secondary Level, M.Ed. Thesis, Tamilnadu Teachers Education University, Chennai.

Williams, J.E. (1993). The relationship of Test Anxiety and Self-concept to Patterns of High School Students Achievement. Journal Midwestern - Educational Researcher, .6(2), pp. 7-12. 